\title{
Short Communication: The Biology of Natfa People: Bones and Teeth
}

\author{
Abdulla Al-Shorman \\ Department of Anthropology, Faculty of Archaeology and Anthropology, Yarmouk University, Irbid, Jordan
}

ABSTRACT: The archeological site of Natfa is a rural late-antiquity site in northern Jordan. The tomb typology points to two social ranks: the public compared to the few elites who might have controlled wealth allocation. The people died at young ages (under 35 years of age).

The 3rd century AD was a turning point in late antiquity as the Roman Empire collapsed economically due to military invasions by Germanic tribesmen, civil wars, and plague. As a result, the military remained unfunded, and emperors confiscated goods, imposed heavy taxes, and exacted forced labor to overcome the crises. The accumulation of factors resulted in economic havoc and famine (Jones, 1964). The third century crises and weakness of the Roman Empire lessened its authority in the east, where turmoil and instability would have occurred. Many of the people in the east Empire were pushed into marginal lands away from cities to seek their livelihoods in food production.

During this time, the majority of people lived in small rural sites that became economically independent. Economic prosperity was obvious in many rural sites in Jordan and the region (Kingsley and Decker, 2001; Mango, 1980; Parker, 1999; Ward-Perkins, 2000a,b; Watson, 2001). This prosperity included wine trade, the import of skilled craftsmen, and the building of fancy tombs.

The present study reviews the tomb architecture and the human skeletons at Natfa in northern Jordan. The site is located $4 \mathrm{~km}$ west of the city of Irbid on a fertile landscape with a varied terrain, where the elevation ranges from 620 to about $695 \mathrm{~m}$ above sea level. Cemeteries were found on the steep slopes of two opposing mountains at an elevation of about $650 \mathrm{~m}$. The site was excavated jointly by Yarmouk University and the University of Arkansas starting in the summer of 2005. This is a rural late antiquity site in the north of Jordan. Successive excavations have revealed tombs, artifacts, cisterns, and archeological structures.

There are 39 excavated tombs at the site, and all are horizontal shaft tombs with or without an arched entrance sometimes leading to loculi (Fig. 1) except for tomb 21 that is a horizontal chamber tomb with radiating loculi (Fig. 2). There is evidence of tomb robbing both in antiquity and in modern times. The recovered bones
There seems to be reliance on hard food particles rich in carbohydrates, which increased the occurrence of interproximal caries. A few oblique dental caries are reported, probably caused by using teeth as tools. Dental Anthropology 2008;21(1):18-20.

were commingled except for 5 individuals.

\section{RESULTS AND DISCUSSION}

Due to the nature of the bones, we were able to sex 9 skeletons using the standards of Buikstra and Ubelaker (1994); 4 were female and 5 male. Seven of the burials could be aged, with a range of from 7 to 35 years. None of these human remains show any paleopathological lesion except for an osteophytosis in one lumbar vertebra.

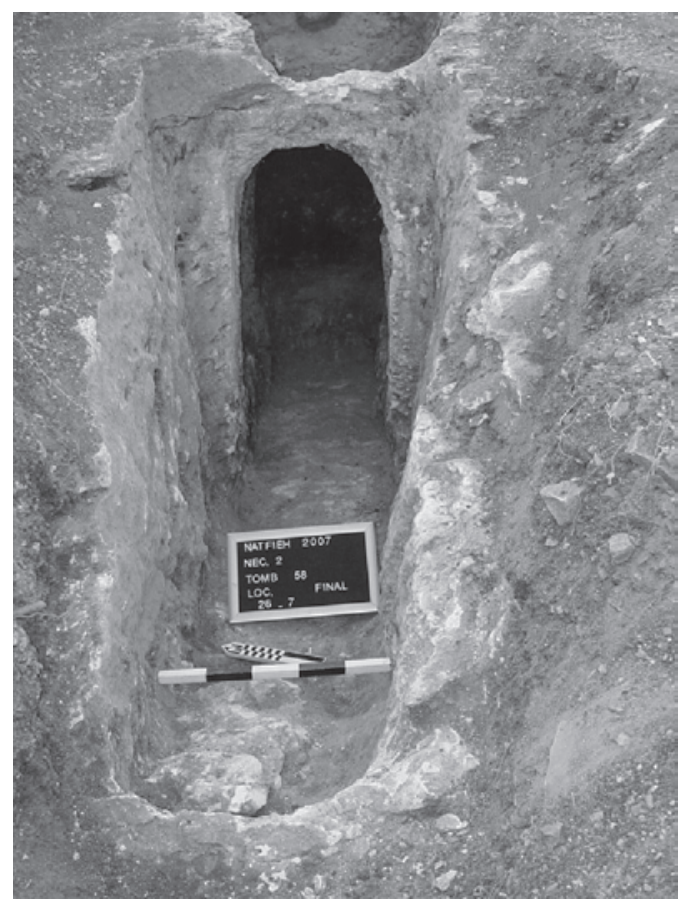

Fig. 1. A horizontal shaft tomb from Natfa with an arched entrance.

Correspondence to: Abdulla Al-Shorman, Department of Anthropology, Faculty of Archaeology and Anthropology, Yarmouk University, Irbid, Jordan.

E-mail: alshorman@yu.edu.jo 
The examined teeth showed marked hypoplasia on most of the anterior teeth (Fig. 4). The average dental wear score for the anterior teeth is 6 (namely, large dentine area with enamel rim lost on one side), and average dental wear on the posterior teeth is 23 (moderate dentine exposure). The few recovered teeth show only interproximal caries in an advanced stage of wear (i.e., exposed pulp cavities).

A few cases of oblique dental wear were recorded, where enamel was lost obliquely down to the labial and buccal root cervix (Fig. 5).

Excluding tomb 21, the tomb typology at the site of Natfa was simple (horizontal shafts) and did not required extensive energy expenditure for construction. According to Binford (1971) and Tainter (1975) greater energy expenditure in tomb construction (and tomb complexity) corresponds to higher social rank of the deceased. This probably means that the horizontal shaft tombs were constructed for the public, while tomb 21 was for elites.

Based on the biological data extracted from the skeletal remains and teeth, the diet of the people of Natfa was moderately hard as the average score of dental wear for the posterior teeth is moderate. This type of wear has been associated with abrasive diets of a vegetable type rich in carbohydrates, mostly cereals. Considerable amounts of cereals and legumes were present in the diets of the Mediterranean region during the Roman period (Prowse et al., 2004; Garnsey, 1999), which extensively wear the enamel.

The interproximal caries are explained by dental wear; in groups whose nutrition is based on foods that abrade grinding surfaces, higher frequencies of interproximal caries are recorded (Calglar et al., 2007) because the wear removes food particles and bacteria.

Although the number of recorded oblique dental wear is few, it stresses the use of teeth as tools. Oblique dental wear is noticed in societies who used their teeth in nonalimentary activities such as tooth-tool use and the use of teeth as a third hand (Minozzi et al., 2003), including leather processing by Eskimos (Merbs, 1983),

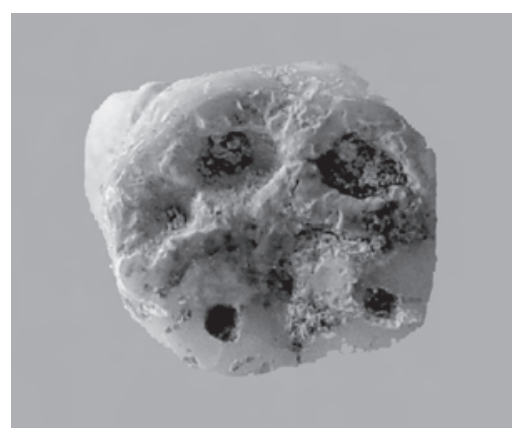

Fig. 3. The moderate dental wear on the posterior teeth.

sinew processing by Australian aboriginals (Brown and Molnar, 1990), basket production by Native American Paiute (Wheat, 1967), and weaving by the Byzantines in Khirbit Yajuz, Jordan (Al-Shorman and Khalil, 2006).

\section{CONCLUSIONS}

The late Roman people of Natfa experienced environmental stresses. They died at young ages, evidently by around 35 years. As their skeletal remains were healthy, nothing could be inferred about the cause of death. The society was stratified into wealthy and poor. Rural sites such as Natfa may have established their economic independence at the expense of quality of life.

\section{REFERENCES CITED}

Al-Shorman A, Khalil L. 2006. The evidence of weaving at Khirbit Yajuz in Jordan using dental microwear. Int J Dent Anthropol 8:1-9.

Binford R. 1971. Mortuary practices: their study and their potential. In: Brown J, editor. Approaches to the social dimensions of mortuary practices. Mem Soc Am Archaeol 25, p. 6-20.

Brown T, Molnar S. 1990. Interproximal grooving and task activity in Australia. Am J Phys Anthropol 81:545-553.

Buikstra JE, Ubelaker DH. 1994. Standards for data collection from human skeletal remains: Proceedings of

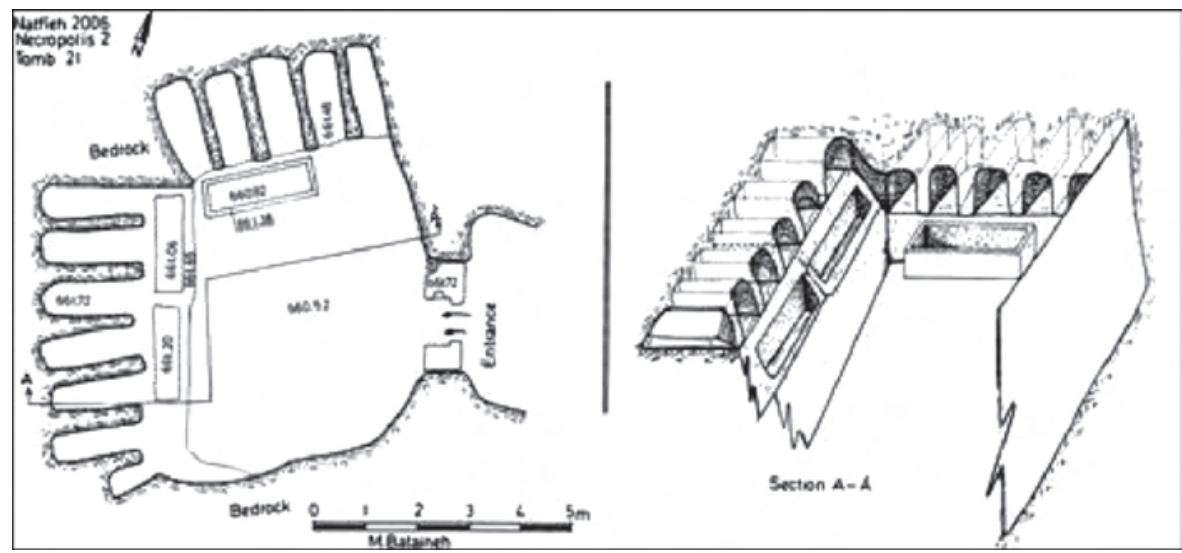

Fig. 2. (Left) Top plan and a 3-dimensional representation of tomb 21; (right) a horizontal chamber tomb at Natfa. 


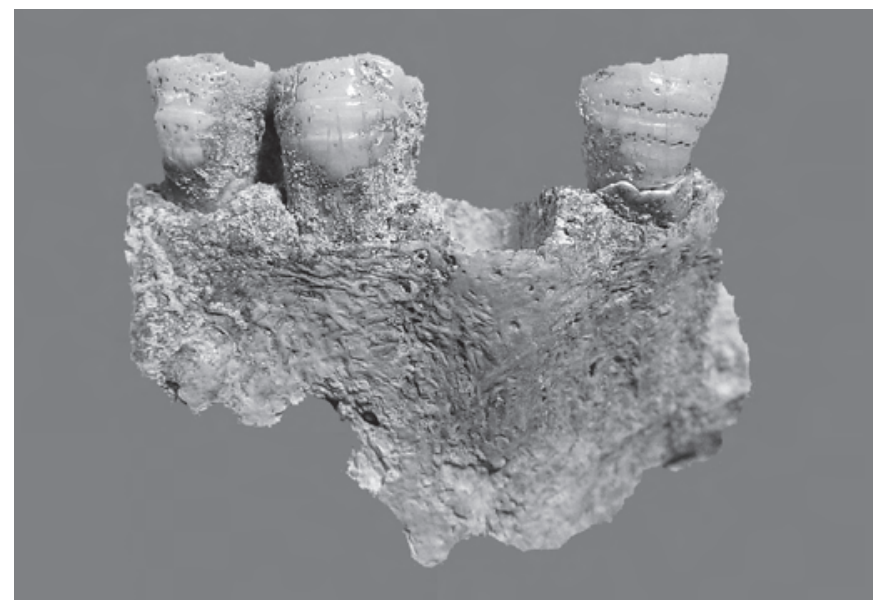

Fig. 4. Marked hypoplasia on the anterior teeth.

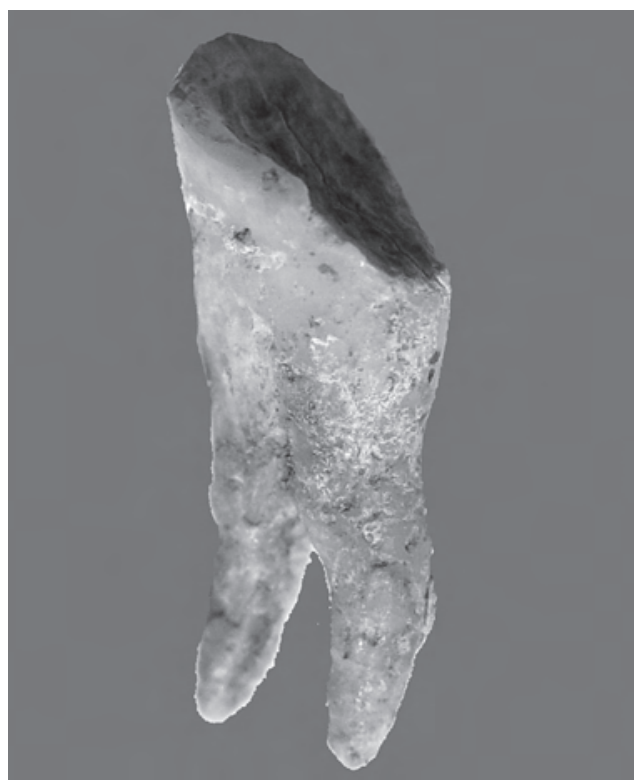

Fig. 5. Oblique dental wear on the upper first premolar.

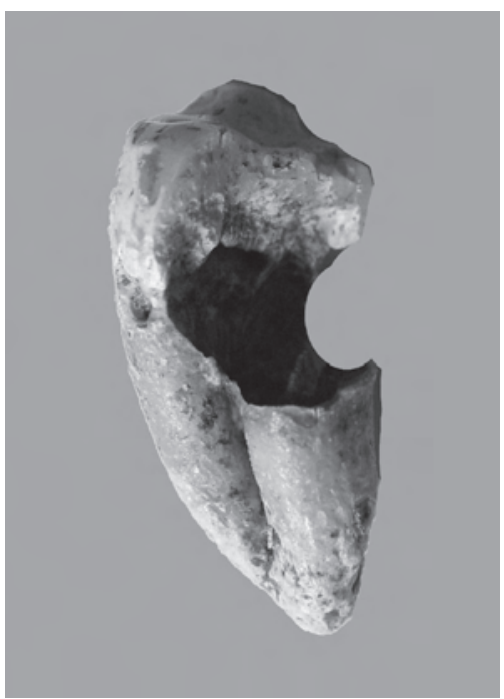

Fig. 6. Interproximal caries in a lower third molar. a seminar at the Field Museum of Natural History (Arkansas Archeological Report Research Series). Fayetteville, AK: Arkansas Archeological Society, 1994.

Calglar E, Kuscu O, Sandalli N, Ari F. 2007. Prevalence of dental caries and tooth wear in a Byzantine population (13th c. AD) from northwest Turkey. Arch Oral Biol [in press].

Garnsey P. 1999. Food and society in Classical Antiquity. Cambridge: Cambridge University Press.

Grant M. 1995. Greek and Roman historians: information and misinformation. New York: Routledge.

Jones A. 1964. The Later Roman Empire 284-602: a social, economic and administrative survey, 3 vols. Oxford: Blackwell.

Kingsley S, Decker M. 2001. Economy and exchange in the East Mediterranean during Late Antiquity. Oxford: Oxbow Books.

Mango C. 1980. Byzantium: the empire of New Rome. London: Wardenfeld and Nicolson.

Merbs C. 1983. Patterns of activity-induced pathology in a Canadian Inuit population. Ottawa: National Museum of Man Mercury Series, Archaeological Survey of Canada Papers, no. 119.

Minnozi S, Moazi G, Ricci F, Lernia S, Tarli S. 2003. Nonalimentary tooth use in prehistory: an example from Early Holocene in central Sahara (Von Muhuggiag Tadrart Acacus, Libya). Am J Phys Anthropol 120:225-232.

Parker S. 1999. The Byzantine Period: an empire's New Holy Land. Near Eastern Archaeology 6:134-181.

Prowse T, Henry P, Schwarcz H, Saunders S, Macchiarelli R, Bondioli L. 2004. Isotopic paleodiet studies of skeletons from the Imperial Roman-Age cemetery of Isola Sacra, Rome, Italy. J Arch Sci 31:259-272.

Tainter J. 1975. Social inference and mortuary practice: an experiment in numerical classification. World Arch 7:1-15.

Ward-Perkins B. 2000a. Land, labor and settlement. In: Cameron B, Ward-Perkins B, Whitby M, editors. The Cambridge Ancient History. Cambridge: Cambridge University Press, p. 315-341.

Ward-Perkins B. 2000b. Specialized production and exchange. In: Cameron B, Ward-Perkins B, Whitby $\mathrm{M}$, editors. The Cambridge Ancient History. Cambridge: Cambridge University Press, p. 346-389.

Watson P. 2001. The Byzantine period. In: MacDonald B, Adams R, Bienkowski P, editors. The Archaeology of Jordan. Sheffield, UK: Sheffield Academic Press.

Wheat M. 1967. Survival arts of the primitive Paiutes. Reno: University of Nevada Press.

White, K. 1976. Food requirements and food supplies in Classical times in relation to the diets of the various classes. Progress in Food Nutrition and Science 2:143-191. 